\title{
Universiteit
}

The Netherlands

\section{Leiden Policy Recommendations on Counter-terrorism and International} Law

Herik, L.J. van den; Schrijver, N.J.

\section{Citation}

Herik, L. J. van den, \& Schrijver, N. J. (2010). Leiden Policy Recommendations on Counterterrorism and International Law. Netherlands International Law Review, 57(3), 531-550. Retrieved from https://hdl.handle.net/1887/42298

Version: $\quad$ Not Applicable (or Unknown)

License:

Downloaded from: https://hdl.handle.net/1887/42298

Note: To cite this publication please use the final published version (if applicable). 


\title{
Leiden Policy Recommendations on Counter-terrorism and International Law
}

\author{
Nico Schrijver and Larissa van den Herik
}

1 April 2010

\section{Introduction}

1. This set of policy recommendations emanates from a consultative process which was concluded on 1 April 2010. Its basic aims are to address the challenges that combating international terrorism poses to international law and to contribute to the international debate on selected contemporary issues in the struggle against international terrorism. It involved approximately thirty experts from a variety of professional and geographical backgrounds, taking part in their personal capacity.

2. The process started with the Oud-Poelgeest conference, which was convened on 10 to 13 April 2007 by the Grotius Centre for International Legal Studies of Leiden University and Campus The Hague. This conference of eminent persons at the Oud-Poelgeest estate, close to the city of Leiden, was organized with the full support of the Netherlands Ministry of Foreign Affairs. The 2007 conference resulted in a report addressing a variety of challenges to current international law resulting from the struggle against terrorism and providing suggestions for a follow-up process. ${ }^{1}$ The report addressed the need to agree on a definition of terrorism; the use of force in self-defence against terrorist acts; the interrelationship between human rights

\footnotetext{
${ }^{1}$ The final report of the Poelgeest Seminar was submitted to parliament by minister Verhagen of Foreign Affairs by letter of 25 June 2007, parliamentary document $27925 \mathrm{nr}$. 255; the report was also published in the Netherlands International Law Review, vol. 54 (2007), no. 3, pp. 571-587.
} 
law and international humanitarian law; the need for closer cooperation between states in criminal matters; the issue of law enforcement in fragile states; and the need for a preventive and integrated approach.

3. A follow-up project was launched in 2008 with a three-fold focus. First, it examined questions relating to law enforcement and criminal justice outside the context of armed conflict and the need to improve international cooperation in the investigation and prosecution of terrorist acts. Secondly, it studied operations that include the transboundary use of force, and in particular the use of force in self-defence against non-state actors. Once armed force is used, the question regarding the applicability of international humanitarian law arises including its relationship to human rights law. The third object of study concerned the specific relationship between international humanitarian law and human rights law. Three working groups were established, with two co-chairs each. The co-chairs were respectively Anton du Plessis and Michael Newton (working group 1), Andrea Bianchi and Sir Michael Wood (working group 2), and Helen Duffy and Jelena Pejic (working group 3). A list of participating experts can be found in annex 1. The project was coordinated by Nico Schrijver and Larissa van den Herik of the Grotius Centre of Leiden University.

4. On 1 April 2010, the combined recommendations resulting from the three working groups were offered to the Netherlands Minister of Foreign Affairs, Maxime Verhagen. As stated above, this set of interrelated and policy-relevant recommendations is the product of a group process. The recommendations are not attributable to any particular expert. They do not necessarily reflect the individual views of all experts. The individual experts concentrated their efforts on the work of their own respective groups and endorsed the specific recommendations of their own group only. The background papers, to be published in an edited volume, contain further pertinent recommendations of the individual authors of the respective working groups.

5. These recommendations aim to contribute to the debate on the role of international law in countering terrorism. They provide expert perspectives on areas in which greater consensus needs to be pursued. 


\section{Part I}

\section{Improving International Cooperation in the Investigation \& Prosecution of Terrorist Acts}

\section{Aim And Scope of the Policy Recommendations}

6. Improving inter-state cooperation in the investigation and prosecution of terrorist acts is vital for a well functioning universal criminal justice approach towards terrorism. States must work towards comprehensive implementation of the relevant international and regional counter-terrorism legal instruments and compliance with relevant UN Security Council resolutions. Terrorist cases involve complex intersections of human rights principles, executive discretion, national security interests, and the larger imperatives of human security. Justice is a moral imperative in its own right, but is also an essential obligation for governments that seek to preserve human dignity and strengthen the social contract with their citizenry.

7. Contemporary terrorist acts often implicate the citizens of one state, but may involve the complicity of nationals of other nations, or assistance in the form of funding and training originating from outside sovereign boundaries. The need for enhanced international criminal justice cooperation in terrorist cases is therefore a vital component of any effective and sustainable global response to terrorism. The discussions largely avoided reference to the body of norms regulating the conduct of hostilities or consideration of the possible enforcement of the jus in bello using forums or principles derived from international humanitarian law. In light of international obligations, however, the improvement of regional and bilateral mechanisms that facilitate domestic criminal and civil justice enforcement efforts is the sine qua non of progress towards an integrated system that promotes fair and human rights-compliant criminal justice responses to terrorism. These recommendations are aimed at developing workable and pragmatic approaches and suggestions. 


\section{SUFFICIENCY OF THE EXISTING FRAMEWORK}

8. Despite the challenges in reaching a comprehensive multilateral definition of terrorism, the existing framework of multilateral instruments provides sufficient legal basis for domestic prosecution of terrorist crimes (defined in the $16 \mathrm{UN}$ instruments and relevant regional counter-terrorism instruments) and international cooperation. The importance of domestic prosecutions and international cooperation is highlighted by the fact that there currently exists no international forum for prosecuting acts of terrorism ${ }^{2}$ and it is unlikely, and undesirable, that the Rome Statute of the International Criminal Court will be amended to include terrorism as a specifically articulated crime. Domestic states should cooperate to eradicate terrorism to the fullest extent possible based on the unequivocal condemnation of all acts, methods, and practices of terrorism as criminal and unjustifiable committed wherever and by whoever.

\section{Strengthen the Domestic Capacity for Investigation and Prosecution of TERRORIST CASES}

9. Effective international cooperation requires respect for human rights. Criminal justice response to terrorism (which includes the investigation, prosecution, and adjudication of terrorist crimes) forms the cornerstone of any sustainable counter-terrorism effort that respects the principles of the rule of law, human rights, and due process. The recent record demonstrates that the reliance on extrajudicial methods has undermined respect for and protection of human rights. In particular, the extrajudicial transfer of terrorist suspects (known as extraordinary rendition) has become emblematic of this problem. The disregard for fundamental human rights norms also has the demonstrable effect of undermining international cooperation in the struggle against suspected terrorists, as well as eroding the available channels for assisting investigations and prosecutions related to transnational terrorist acts, particularly those that cross regional boundaries. The absence of an effective and efficient regime for international cooperation can result in frustration among law enforcement and security officials that in turn leads to human rights violations. This is particularly important when dealing with fragile states.

\footnotetext{
2 The Working Group recognizes the limited mandate of the Lebanon Tribunal that may include prosecution of terrorist acts.
} 
10. For the purposes of international cooperation, there is no compelling need for renewed diplomatic efforts to be expended on developing new multilateral instruments. There is an existing network of bilateral and multilateral treaties as well as domestic law that is sufficient for criminalization and effective and efficient international cooperation, especially in counter-terrorism.

11. The central challenge, however, is the lack of adoption, ratification, accession, and most significantly, implementation of the existing instruments and mechanisms. There are striking gaps across regions in state practice in this regard, and there is a need for increased domestic criminal justice capability as part of an overarching and integrated development agenda in order to achieve the goals of the respective multilateral instruments.

12. In addition, widespread, consistent, and appropriately defined domestic criminalization of terrorist acts will facilitate effective international cooperation. This would enhance the ability of states to comply with their obligations to "prosecute or extradite" as mandated by the international and regional counter-terrorism regimes. There is a pressing need for more states to embed prohibitions on terrorist acts within their domestic legislation along with comprehensive cooperative regimes. Extensive reliance on special anti-terrorism legislation that creates extended administrative detention regimes should be avoided.

\section{REINFORCED DOMESTIC SYSTEMS DEPEND ON IMPROVED AND APPROPRIATE INTERNATIONAL COOPERATION}

13. Despite discernible islands of cooperation, the overall cooperative regime is being implemented in an uneven manner. There is a need across all regions for legislation which adopts a more flexible approach to international cooperation in criminal matters. On the operational level, a strengthened and knowledgeable central authority is essential to improving international cooperation. At present, the proliferation of multiple central authorities with overlapping mandates hinders effective international and inter-agency cooperation. In addition, the poor quality and clarity of many requests for international assistance is a critical barrier to effective cooperation. In this regard, there are available tools that are, at present, underutilized. One specific example is the UNODC Mutual Legal Assistance Request writer tool. 
14. The default approach by which many domestic bureaucracies and regulations commingle the extradition regime with that applicable to information sharing and evidence gathering must be reevaluated and redesigned. The principles and restrictions that govern extradition practice have been inappropriately (and unnecessarily) fused into the practice of mutual legal assistance, with the predictable effect of hindering investigations and the free flow of information. This is a radical but much needed shift because of the deeply ingrained habits of approaching extradition and evidence gathering as nearly identical processes with the same procedural requirements and the same need for protections. The practice must be reframed to approach evidence gathering as a distinct process which should move much more rapidly and be effectively synthesized into ongoing investigations.

15. One key approach to improving international cooperation is to dramatically expand the establishment of national joint investigation teams which has the collateral benefit of eliminating the barriers to information sharing that are commonly encountered when information has been derived through intelligence channels and classified as such by domestic authorities. Such joint investigative teams should be interdisciplinary and operated on the basis of agreed upon procedures and practices. An additional benefit of this approach is to integrate prosecutorial expertise in a more visible and vibrant role at an earlier stage.

\section{SHARING SENSITIVE INFORMATION}

16. The transnational character of modern terrorism means that intelligence and law enforcement agencies must increasingly share information with their foreign counterparts. This cooperation often involves working with states that have few domestic human rights safeguards, or, worse still, with foreign intelligence agencies that have long histories of involvement in systematic human rights violations. States should ensure that national intelligence services have clear guidance and appropriate oversight mechanisms that do not hinder the free flow of timely intelligence among nations. Information should be declassified and disseminated as rapidly as possible when needed to disrupt terrorist operations.

17. In addition, the roles and responsibilities of intelligence officials and law enforcement authorities should be clearly defined. There are processes that can and should be replicated across domestic jurisdictions that provide workable methods for protecting sources and 
methods, while still complying with the human rights of defendants facing trial for specific acts.

\section{THE IMPORTANCE OF REgIONAL ORGANIZATIONS}

18. Regional organizations play an important role in promoting cooperation and information sharing in counter-terrorism matters. They also facilitate capacity building to states in various areas of counter-terrorism, including intelligence gathering, financial cooperation, and mutual legal assistance. Informal mechanisms often provide the impetus and opportunity for improved cooperation. Regional organizations are an irreplaceable venue for establishing and enforcing the legal and procedural frameworks for counter-terrorism cooperation. Regional mechanisms supplement but do not replace the framework of cooperation from international multilateral instruments and UN channels.

19. Terrorist organizations have become adept at exploiting regional animosities and finding the rifts in bilateral relations to conduct operations. Regional organizations can play the decisive role in building trust between national actors that leads to more effective and timely cooperation that can produce notable improvements in the common effort to prevent and/or punish terrorist acts.

20. Successful practices of regional organizations, such as the European Arrest Warrant and EUROJUST should inform practices in other regions. One key lesson from EUROJUST and the European Arrest Warrant is that mutual trust is the cornerstone of more efficient and streamlined cooperation procedures. In particular, building mutual trust contributes to more effective international cooperation such as the elimination of barriers created by dual criminality, transnational recognition of search warrants, and wider recognition of asset freezing and confiscation orders.

\section{INCREASED USE OF MULTIDISCIPLINARY FUSION CENTRES}

21. Multidisciplinary fusion centres are a critical tool to facilitate the earlier involvement of prosecutorial expertise in terrorism investigations. Integration of experts from a number of nations and professional disciplines would also provide an integrated forum for enhancing international cooperation in relation to fragile states. States should reexamine their national 
laws in this regard to ensure that progress can be made in assisting transregional investigations. Multidisciplinary fusion centres can also provide available staff and integrated operational framework for rapid movement into areas affected by terrorist acts following a request by the sovereign government.

\section{INTERNATIONAL COOPERATION IN COUNTERING THE FINANCING OF TERRORISM}

22. Stemming the flow of terrorist finances is a crucial component of the fight against terrorism. Following the flow of terrorist finances may lead to invaluable information that can assist investigators in uncovering terrorist activities. The financing of terrorism was an early target of the international effort to combat terrorism. Security Council resolutions 1267 and 1373 were designed to promote international co-operation in the pursuit and freezing of assets believed to be connected with terrorists or terrorist organisations. Legislation to implement those resolutions has been the subject of numerous challenges, especially in relation to the due process concerns associated with the 1267 regime. On the other hand, the Convention on the Suppression of the Financing of Terrorism does provide another important tool in the fight against terrorist financing. It requires States Parties to implement specific measures, including innovative asset freezing and confiscation regimes.

23. Global implementation of this regime is inconsistent. For example, many EU states have not implemented some of the basic measures to give effect to these obligations. For example, an EU - US Agreement on mutual legal assistance which includes important provisions on access to bank accounts is not in force. At the regional level, a number of states have not signed and ratified the 2005 Warsaw Convention on Money Laundering and Terrorist Financing. Under the Warsaw Convention, States Parties are required to 'co-operate to the widest extent possible under their domestic law with those Parties which request the execution of measures equivalent to confiscation leading to the deprivation of property, which are not criminal sanctions, in so far as such measures are ordered by a judicial authority of the requesting Party in relation to a criminal offence'.

24. There should be a greater emphasis on non-conviction based forfeiture of assets. This does not imply agreement with the expanded use of the Security Council resolution 1267 regime. On the contrary, in keeping with the earlier focus on the protection of fundamental human rights, a revitalized regime for freezing and/or confiscation of the proceeds or 
instrumentalities of terrorist crimes should be based on direct enforcement with judicial oversight and safeguards designed to prevent misuse of the regime for politicized purposes.

25. Unlike criminal forfeiture, which requires a criminal trial and conviction, civil forfeiture is an action in rem against the asset itself, not the individual. The World Bank, under its Stolen Asset Recovery (StAR) initiative, produced a "Good Practices Guide" for non-conviction based asset forfeiture which encourages those states which do not already provide for such forfeiture to introduce the necessary measures. In addition, widespread ratification of the Warsaw Convention noted above could create more opportunities to enforce civil confiscation orders in other countries.

26. EU states should seek a new agreement with the United States on the processing and transfer of financial messaging data. The interdiction of funding streams is a vital tool in protecting society and preserving human rights. Tracking the flow of terrorist financing is also an essential component of many successful prosecutions and hence must be a high priority for the future of transnational cooperative efforts.

\section{SPECIFIC POLICY RECOMMENDATIONS}

1.) Effective and sustainable transnational cooperation to prevent or counter terrorist acts should respect human rights and due process standards.

2.) There is no compelling need for new multilateral international cooperation treaties. There is, however, an urgent need for increased ratification and implementation of existing agreements.

3.) More states should criminalize the terrorist acts defined by the relevant multilateral and regional treaties in order to eliminate existing barriers to their obligation to prosecute or extradite terrorist suspects.

4.) Proliferation of national Central Authorities with overlapping mandates and unclear authority should be avoided.

5.) As distinct from the policy and practice applicable to extradition, the practice of mutual legal assistance must be reframed to ensure timely and flexible international cooperation. 
6.) National intelligence agencies should have clear guidance and oversight mechanisms that appropriately complement the roles and responsibilities of law enforcement authorities.

7.) Regional organizations have an irreplaceable role supporting the development of policy and practice on international cooperation, and should be used when possible to build capacity in domestic judicial and investigative systems.

8.) Multidisciplinary fusion centres should be used where possible as an integrated forum to enhance international cooperation and provide specialized prosecutorial expertise at an early point in investigations.

9.) States should increase their ability to interdict the flow of terrorist financing, and in particular should expand the processes available for non-conviction based forfeitures of assets under judicial oversight. 


\section{Part II}

\section{The Use of Force against Terrorists}

27. As stated in the conclusions of Part I, terrorism should be primarily dealt with at the level of national criminal justice systems. Force should be used only as a last resort.

\section{Aim And Scope of the Policy Recommendations}

28. There is no need for new rules of general international law to deal with the use of force in relation to international terrorism. The framework laid down in the UN Charter is the cornerstone of the international legal regime on the use of force and states are deeply committed to it. However, the Charter is not a static instrument and needs to be interpreted in the light of contemporary practice and taking states' expectations into account. States are encouraged to express their views promptly and openly, in all available fora, on the legality (or lack thereof) of any instance in which force is used. This will contribute to establishing or consolidating international consensus over the applicable rules.

29. The aim of the following policy recommendations is twofold. On the one hand, they aim at clarifying the state of international law on the use of force against terrorists against the backdrop of recent practice. On the other, they intend to highlight areas in which greater consensus needs to be pursued at the international level. The recommendations focus on the issues most relevant to the use of force against terrorists, ranging from the role of the Security Council and the notion of armed attack, to the requirements for the exercise of self-defence and, particularly, of anticipatory self-defence. Finally due heed is paid to the specific issue of the use of force against terrorist groups operating from the territory of fragile states.

\section{USE OF ForCe AS Measure OF LAST RESORT}

30. All efforts should be made to exhaust means other than force to prevent and repress terrorist activities. States and the Security Council should give priority, wherever possible, to law enforcement measures and recognise that the use of force is a measure of last resort, to be employed only where absolutely necessary. 
31. Article 2(4) of the Charter prohibits states from using force, or threatening to do so, against the territorial integrity or political independence of any state or in any other manner inconsistent with the Purposes of the United Nations. This core provision of contemporary international law bans coercive military action by a state against another state, meaning any such action on the latter's territory, and in some circumstances action against its assets abroad. This prohibition includes coercive military action against other states as a response to terrorist acts. The two exceptions to this prohibition are: (a) Security Council authorization for a state to use force, and (b) the use of force in self-defence in response to an armed attack, or an imminent threat thereof, in accordance with Article 51 of the Charter.

32. It should be emphasised that states considering the use of force against terrorists must take due account of the exceptional nature of military action on foreign territory. The territorial state's consent to military action is required, except where the territorial state is unable or unwilling itself to deal with the terrorist attacks.

33. In any use of military force states must comply with applicable rules of international humanitarian law and human rights law.

\section{The Role of THE Security COUNCIL}

34. According to the UN Charter, the Security Council has primary responsibility for the maintenance of international peace and security. States should consider enhancing the Security Council's role in respect of the use of force against terrorists, so as to develop multilateral approaches to the matter wherever possible. This is best done case-by-case, not by way of a general declaration in a resolution or Presidential statement.

35. Security Council authorisation under Chapter VII is legally necessary for the deployment of force against terrorists in another state without that state's consent, except when the requirements for self-defence are met; even in the case of self-defence the Council has a role under the Charter.

36. Security Council endorsement should be seen as politically desirable, even in cases of self-defence (and need not affect the right of self-defence). Measures taken with Security 
Council endorsement will have stronger domestic and international support, and for that reason should be more effective than if taken without such endorsement. A state contemplating the use of force in self-defence against terrorists should therefore normally first go to the Security Council, except when there is no time, or where the Security Council is manifestly unable to act. Any action taken in self-defence has to be notified to the Security Council and appropriate justification, in light of all relevant circumstances, should be provided.

37. Regional and sub-regional organizations, such as NATO, the African Union and ECOWAS, when playing a role in respect of the use of force against terrorist groups, should not undermine the Security Council's primary responsibility under the Charter.

\section{ARMEd ATtaCK}

38. The recognition in Article 51 of the inherent right of individual or collective selfdefence in the event of an armed attack makes no reference to the source of the armed attack. It is now well accepted that attacks by non-state actors, even when not acting on behalf of a state, can trigger a state's right of individual and collective (upon request of the victim state) self-defence. A state that is the victim of an armed attack by terrorists may thus take action against those non-state actors operating from another state, although the scope of that response will depend upon a variety of factors and requirements discussed below.

39. Article 51 does not include a scale requirement for an armed attack, and there is disagreement on the existence and contours of such a requirement in the case of an attack by one state on another. In the case of an attack by terrorists that is not attributable to a state, Article 51 should be read to require that the attack be large-scale in order to trigger the right of self-defence; in assessing the scale, account may be taken of a series of attacks emanating from the same territory and the same terrorist group. The heightened threshold stems from the critical role of the state(s) on whose territory terrorists operate and the primary responsibility of such state(s) for the prevention and suppression of such acts. It recognizes that such a state or states would be affected by the force used in self-defence and ensures that self-defence and the consequences for that state or states that flow from a military response are not triggered too soon. 


\section{SELF-DEFENCE REQUIREMENTS}

40. A state exercising self-defence must respect the limits of necessity and proportionality. Both conditions are fully applicable to self-defence against terrorist attacks emanating from the territory of another state. Where the terrorist attacks emanate from more than one state those conditions must be assessed in relation to each state.

41. The use of force in self-defence is justified only when force is necessary to bring an attack to an end, or to avert an imminent attack (under the conditions discussed below). Force is not necessary, for example, if the terrorist acts can be dealt with by measures of law enforcement.

42. The requirement of necessity must first be assessed in the light of the actions of the state from the territory of which the terrorist acts emanate. Where a state is itself supporting or encouraging the actions of terrorists on its territory, it may well be unwilling to avert or repel the attack and action in self-defence may be necessary. Self-defence may also be necessary if the armed attack cannot be repelled or averted by the territorial state. States relying on self-defence therefore must show that the territorial state's action is not effective in countering the terrorist threat. Whether this is the case depends on circumstances such as the nature and gravity of the threat, including the territorial state's attitude vis-à-vis the group operating on its territory. Being an inherent right to repel or avert attacks, self-defence does not require that armed attacks by terrorists be attributable to the territorial state under the rules of state responsibility.

43. In order to be proportionate, measures of self-defence must be limited to what is required to repel or avert the armed attack. Proportionality in this sense requires states regularly to monitor on-going measures of self-defence and ensure that they remain defensive in character. This may entail limitations on the intensity and duration of force employed and on the theatre and target of operations. In particular, it will normally mean that measures of self-defence against suspected terrorists must be directed primarily against the terrorist groups responsible for the armed attack in question or their facilities. Only in exceptional circumstances will self-defence justify the use of force against the armed forces or facilities of the territorial state, for example, in circumstances where the territorial state is supporting suspected terrorists, as in Afghanistan in 2001. 
44. Unnecessary or disproportionate use of force cannot be justified as a measure of selfdefence under international law. As the application of both factors is heavily fact-dependent, states using force in self-defence should be prepared to make publicly available information and data that will support the necessity and proportionality of their conduct. International law does not prevent third states from scrutinising the necessity and proportionality of selfdefence operations or from requesting further evidence.

\section{ANTICIPATORY SELF-DEFENCE}

45. States have a right of self-defence against a threatened attack, but only if the attack is imminent and if the armed action in self-defence is necessary to avert the attack and is proportionate to it. Action to avert a threatened attack is best termed anticipatory self-defence and must be distinguished from the use of so-called 'pre-emptive' or 'preventive' force before a threat has crystallized, which could only be lawful if authorized by the Security Council.

46. Whether an attack may be regarded as imminent falls to be assessed by reference to the immediacy of the attack, its nature, and gravity. There must be a reasonable and objective basis for concluding that an attack will be launched, while bearing in mind that terrorists typically rely on the unpredictability of attacks in order to spread terror among civilians. Armed force may be used only when it is anticipated that delay would result in an inability by the threatened state effectively to avert the attack.

47. As indicated above, it is only exceptionally that the threatened state may take armed action in self-defence against a non-state actor in the territory of another state without first seeking the consent of that state. It will thus be only in the most compelling emergency that there will be necessity for the threatened state itself to take military action before an attack is launched.

48. Any use of force in anticipatory self-defence should be justified publicly by reference to the evidence available to the state concerned; the facts do not speak for themselves, and the state should explain, as fully as it is able to do, the nature of the threat and the necessity for anticipatory military action. 


\section{USE Of ForCe AND FRAgile STATES}

49. The rules on the use of force, set out above, apply equally to non-state actors launching cross-border attacks from a failed state (a state without a functioning government), or from a failing state (a state with a particularly weak government).

50. Even the complete absence of a government does not per se lead to a loss of statehood. Instead, state practice suggests that a fragile state will generally continue to exist as a state under international law over a considerable time. The territory and the population of that state will continue to be protected by the prohibition of the use of force. It follows that the use of force on the territory of a failed or failing state carried out by another state requires legal justification. In the absence of a Security Council authorization under Chapter VII of the UN Charter, the right to self-defence is the only possible legal basis for another state to respond forcibly to a non-state armed attack emanating from a failed or (absent consent) failing state.

51. A fragile state lacks an organ to express its consent to the use of force carried out by another state on the former state's territory. Conversely, the expression of such consent is conceivable in the case of a failing state. State practice suggests that even a government unable to deal with the non-state actors in its own territory can express an internationally valid consent, unless such government lacks international recognition. A failing state unable to avert or halt a non-state armed attack ought to consent to forcible action by other states to act in its place. If it does not do so, action may be taken in self-defence .

52. In the case of a fragile state and, where its government is unable to deal with the nonstate actors, in the case of a failing state, the non-state armed attack cannot be attributed to the state. Nor will the state necessarily incur responsibility for a failure to exercise due diligence to prevent the armed attack. This does not, however, exclude the victim state's right to self-defence because this right can be exercised against non-state armed attacks and does not presuppose the territorial state's responsibility for internationally wrongful conduct. 


\section{Part III}

\section{Intersection Between International Human Rights Law and International Humanitarian Law in the Fight against Terrorism}

\section{Aim And Scope of the Policy Recommendations}

53. States are obliged to take effective measures to prevent terrorist acts and to protect the human rights of their citizens. In so doing, states must act consistently with their obligations under international law, including international human rights law (IHRL) and international humanitarian law (IHL). This injunction recognizes that upholding human rights and protecting the public from terrorist acts are not antithetical, but complementary responsibilities of states. The legitimacy of any measure taken by states to combat terrorism will depend upon compliance with the full range of applicable international law.

54. As pointed out in the Poelgeest Report there is no single answer to the question of which legal regime - human rights law or international humanitarian law - applies in the fight against terrorism. The applicable legal regime and the necessary concurrent application of several legal regimes can only be determined on a case-by-case basis. While the relationship between IHRL and IHL remains an evolving issue, every effort should be made by human rights and humanitarian law experts, whether belonging to governments, international organizations, non-governmental organizations or other actors to get better acquainted with each others' legal and policy perspectives, as well as with the realities of the application of the different bodies of law on the ground.

55. The aim of the recommendations in this Part is to highlight several areas central to defining the relationship between human rights and humanitarian law as a matter of law, policy and practice. The topics are grouped around three headings related to the applicability of the two bodies of law, their interplay on certain specific issues and their interface with other legal frameworks. The recommendations strive to restate existing law on some issues, to provide a reading of what developments in the law might be in others, and to suggest topics for further discussion and follow up by experts and policy-makers at the international 
level on yet others. The recommendations do not purport to address the broad array of IHRL or IHL issues raised by the fight against terrorism.

\section{SECTION 1: APPLICABILITY OF IHRL AND IHL}

\section{APPLiCABILITY OF INTERNATIONAL HUMAN Rights LAW}

56. International human rights law applies at all times and is the body of international law most commonly applicable to counter-terrorist activity, whether at home or abroad. The application of human rights law in situations of armed conflict, alongside IHL, is now beyond reasonable debate.

57. The Human Rights Committee, the European Court of Human Rights and the former European Commission on Human Rights, as well as the Inter-American Commission on Human Rights have all found their respective instruments to apply extraterritorially, even in situations of armed conflict. Clearly, the fact that a state acts beyond its borders does not give rise to the applicability of the full range of positive human rights obligations binding on a state within its own territory. However, obligations do arise in respect of, and commensurate with, the exercise of the state's authority and control abroad. Where the state exercises direct control over individuals, IHRL is in principle applicable. This is of course distinct from the question of the interplay between IHRL and IHL addressed below.

58. An issue on which greater consideration is due is the derogability of human rights treaty obligations by states engaged in military operations in the territory of a third state, whether individually or collectively. Consideration should be given to whether extraterritorial derogability is or should be possible by an intervening state. This issue remains unresolved both in law and practice and should be the subject of further expert debate at the international level.

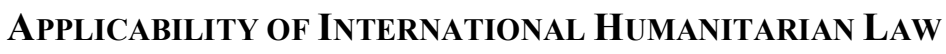

59. Acts of terrorism in themselves do not automatically amount to "armed conflict". The majority of terrorist acts that take place around the world fall outside armed conflict and 
should be dealt with under a law enforcement paradigm. This means that the applicable legal regimes are domestic law, human rights law and international criminal law.

60. The threshold for the application of international humanitarian law (IHL) is the existence of an armed conflict or occupation. It is thus necessary to exercise particular rigor in classifying a situation as an armed conflict so as not to extend IHL application to situations that, objectively, do not amount to armed conflict and where the exclusive application of human rights law is warranted.

61. While international armed conflict involves hostilities between states only, it is more difficult to determine when the threshold of non-international armed conflict under Common Article 3 to the 1949 Geneva Conventions has been reached. A Common Article 3 conflict is one waged between one or more states and one or more organised non-state armed groups or between such groups themselves. It is generally accepted that there are two basic criteria for determining that a situation of violence may be classified as a Common Article 3 conflict: the intensity of the violence involved and the level of organisation of the non-state party to such a conflict.

62. In so far as intensity of violence is concerned, it would include protracted violence meaning that acts are not perpetrated in isolation but as part of an ongoing campaign. It is immaterial whether the acts of violence perpetrated may or may not be characterised as terrorist in nature. With regard to the organisation of the non-state party, an organised group would, inter alia, require a command structure and a leadership with a capacity to exert authority over its members.

63. It is possible for an armed conflict involving non-state actors to extend to the territory of more than one state, without necessarily qualifying as an international armed conflict. Such "transnational" armed conflicts would be subject to IHL applicable to non-international armed conflicts. This will, however, depend on whether, within any particular state, the factual conditions are met for an armed conflict to exist. The application of IHL in one country does not mean that there is a global armed conflict and law enforcement will remain the principal means of dealing with acts of terrorism in countries / places where the armed conflict threshold has not been crossed. 


\section{SECTION 2: INTERPLAY OF IHRL AND IHL ON SPECIFIC ISSUES RELATED TO THE PROTECTION OF PERSONS}

64. Where IHRL and IHL are both applicable, they should, where possible, be interpreted harmoniously. A harmonious approach to interpretation is possible where both bodies of rules have parallel purposes and principles that enable apparent conflicts to be resolved through consistent interpretation. The substantive coherence between the content of IHRL and IHL is extensive, notably in relation to the treatment of persons, fair trial and accountability.

65. However, the complexity of harmonious interpretation must also be recognised. The operation of the lex specialis rule is relevant when there are norms of IHL directed to the particular situation that are at variance with those of IHRL, which arises most obviously in relation to rules on the right to life and detention in armed conflict. A context sensitive application of IHRL and a human rights informed application of IHL may not lead to greatly divergent standards on the vast majority of issues.

66. Attention should be paid to ensuring that all those charged with the implementation of IHRL and IHL understand and apply the relevant bodies of law. Emphasis should be placed on the duties of states to provide guidelines to those on the ground to clarify applicable law, including the inter-relationship of IHRL and IHL in relation to particular situations and norms.

67. Human rights courts and treaty bodies have become increasingly engaged in the adjudication or assessment of human rights violations arising in armed conflict, providing victims with the prospect of a remedy, which may otherwise be elusive. However, these bodies have not always had due regard to IHL in their determinations of human rights issues in armed conflict situations.

68. Accountability for crimes committed in the name of counter-terrorism should be seen as a legal imperative under IHRL and IHL, not a policy alternative. Investigation of serious violations of either IHRL or IHL should be thorough and independent in line with established international standards. The right to reparation of victims of terrorism or of victims of violations committed in the name of fighting international terrorism should be recognised. 


\section{Treatment and Procedural Guarantees for Persons Detained in the Fight AGAINST TERRORISM}

69. Torture or cruel, inhuman or degrading treatment or punishment are absolutely prohibited by both international human rights and international humanitarian law. Calibrating standards of treatment to different categories of detainees, based on the reasons or circumstances of their detention is clearly unlawful. Every effort must be made to ensure that the prohibition of torture or cruel, inhuman and degrading treatment is observed in all places of detention and that persons responsible for possible violations are held to account. "Ticking time-bomb" scenarios do not afford any exception to the prohibition of torture or cruel, inhuman or degrading treatment and should be categorically rejected.

70. Interrogation methods must be in conformity with the prohibition of torture or cruel, inhuman and degrading treatment and must be constantly reviewed to ensure that these prohibitions are respected in practice. While certain forms of treatment (such as mutilation, rape, electric shocks, etc.) per se amount to torture or cruel, inhuman and degrading treatment and are prohibited at all times, it is not possible to draw up finite lists of authorised interrogation methods.

71. Under international law, the use of statements and other evidence obtained by torture or cruel, inhuman and degrading treatment must be excluded from any criminal or other judicial proceedings, except in cases specifically provided for in Article 15 of the Convention against Torture.

72. While humanitarian and human rights law are essentially the same as regards fair trial rights, procedural safeguards for persons detained for posing a serious security threat differ depending on whether detention is governed by international humanitarian or human rights law. The latter mandates court supervision of any type of detention, including security detention, a requirement that may be derogated from only in the exceptional circumstances of a public emergency threatening the life of the nation. There is also a growing body of opinion according to which court supervision of detention can never be derogated from.

73. Humanitarian law deals with a different reality in which there might not be a functioning court system, in which detainee numbers might be significant and in which there 
may be a range of other obstacles to judicial review arising from the battlefield context. Thus, IHL in international armed conflict provides for review of internment based on imperative reasons of security (POW detention is excluded), either by a court or administrative board. There are in certain circumstances particular challenges in implementing procedural safeguards for internment in non-international armed conflicts, which constitute the majority of armed conflicts today. This is an issue which merits further discussion at the international level and, if possible, the elaboration of specific rules or guidelines. In the interim, existing principles and safeguards, such as those proposed by the ICRC in $2005,{ }^{3}$ may be relied on as minimum standards of due process in any type of detention for security reasons.

74. A significant subset of non-international armed conflicts are those in which a coalition of states detains nationals of a "host" state in its territory. The legal and practical problems involved in ensuring procedural safeguards in this type of detention are considerable and as yet not fully understood or explored.

\section{The USE OF Lethal ForCe IN THE Fight Against TerRorisM}

75. The issue of whether the use of lethal force against a person suspected of acts of terrorism is lawful depends on two separate questions: a) whether use of force in a territory which is not under the jurisdiction of the state whose agents employ the force violates the affected state's territorial integrity, and b) whether it involves an arbitrary deprivation of life of the targeted person.

76. Whether use of lethal force against a person is lawful may be judged according to two legal regimes: the law enforcement regime, governed by international human rights law, and rules on the conduct of hostilities governed by the law of armed conflict. IHL is lex specialis, which applies only when there is an ongoing armed conflict and the targeting has a nexus to the hostilities connected with that conflict.

\footnotetext{
${ }^{3}$ See J. Pejic, 'Procedural Principles and Safeguards for Internment/Administrative Detention in Armed Conflict and Other Situations of Violence', International Review of the Red Cross, Vol. 87, No. 858, June 2005. It was published as Annex 1 to an ICRC Report on 'International Humanitarian Law and the Challenges of Contemporary Armed Conflicts' presented to the $30^{\text {th }}$ International Conference of the Red Cross and Red Crescent held in Geneva in 2007 and reflects the ICRC's institutional position. See http://www.icrc.org/Web/Eng/siteeng0.nsf/htmlall/p0892/\$File/ICRC_002_0892.PDF.
} 
77. Under the law enforcement regime governed by human rights law, a person may be targeted only when use of lethal force is absolutely necessary to protect others from unlawful violence. This is generally taken to mean that the unlawful violence is imminent, leaving no room or time for the employment of non-lethal methods of law enforcement. In IHL the use of lethal force is regulated by rules on the conduct of hostilities, which include provisions on the protection of civilians against direct attack unless and for such time as they take a direct part in hostilities.

\section{Transfer of Persons in the Fight against Terrorism}

78. Human rights, refugee law, and humanitarian law protect individuals when they are transferred from the custody of one state to another. A minimum baseline standard which should be applied as regards transfers pertains to: threshold principles, substantive guarantees of non-refoulement and procedural guarantees. At least two threshold principles should be observed. The first is that formal procedures for transfer, such as extradition or deportation, may not be intentionally bypassed, and the second is that the transferring state should have a valid legal basis for apprehending the individual in contemplation of transfer.

79. It is generally accepted that there may be no transfers to a real risk: of torture or cruel, inhuman or degrading treatment; of persecution; of enforced disappearance; or of arbitrary deprivation of life.

80. The relevant procedural guarantees include the ability of the affected person to challenge the basis for his or her apprehension/detention and his or her ability to challenge transfer based on the grounds provided for in international law. Procedural safeguards also include a person's ability to challenge transfer before it takes place, before an independent decision-maker. Resort to diplomatic assurances can never per se obviate the risk of serious violations referred to above. Where diplomatic assurances are used, as one element in the assessment of risk, they should be accompanied by rigorous safeguards such as judicial review and effective post-return monitoring by the transferring state.

81. The legal, practical and policy implications relating to the transfer of persons in the fight against terrorism are believed to require further expert discussion at the international level. 


\section{SECTION 3: INTERSECTIONS WITH OTHER LEGAL FRAMEWORKS}

\section{Obligations regarding Peace and Security and the Protection of Persons}

82. Problems have arisen for the application of IHRL and IHL in relation to Security Council resolutions and their implementation. Examples include issues relating to the detention of persons and the freezing of assets.

83. States have a responsibility to implement Security Council resolutions. In the exercise of their discretion in the choice of methods of implementation, they should ensure conformity with human rights, international humanitarian law and other relevant bodies of international law. Lack of accountability for violations of IHRL and IHL arising in the implementation of counter-terrorism resolutions leads to a denial of access to justice for victims and should be avoided.

84. The Security Council cannot authorize violations of human rights and IHL norms that rise to the level of jus cogens. The Security Council should, moreover, take full account of the UN's own Global Counter-Terrorism Strategy, which centres the protection and promotion of human rights as an integral part of any effective and sustainable counterterrorism approach. Where Security Council resolutions are unclear, there should be a presumption that the Security Council does not intend that actions taken pursuant to its resolutions should violate international human rights and international humanitarian law.

85. The Security Council should avoid placing states in situations where their obligations regarding peace and security and under IHRL and IHL cannot be simultaneously respected. The human rights impact of all draft counter-terrorism resolutions should be thoroughly considered. Consideration should also be given to on-going monitoring and conducting human rights impact assessments of all counter-terrorism resolutions.

86. The relationship between states' obligations regarding international peace and security and states' obligations for the protection of persons deserves further attention by experts at the international level. 


\section{Terrorism AND CRIMINAL JUSTICE}

87. Acts of violence carried out in the context of an international or non-international armed conflict are governed by the rules of international humanitarian law and should remain excluded from the notion of international terrorism under the criminal justice regime. Deliberate attacks against civilians and civilian objects are considered war crimes under international humanitarian law; consequently, the perpetrators of these acts may be prosecuted in domestic and international courts.

88. Consistent efforts should be made to ensure that legislation enacted to criminalise acts of terrorism in a State's domestic jurisdiction respects the non-derogable principle nullum crimen sine lege (the principle of legality). Counter-terrorism legislation should not jeopardize the rights to freedom of expression and association nor unduly restrict the due process rights of those accused of committing acts of terrorism.

89. Violations of fundamental human rights such as the right not to be subject to torture or other forms of ill treatment may hamper the criminal prosecution of suspected terrorists and have a negative impact on international cooperation in criminal matters. States must abide by the fundamental principles of due process in the collection of evidence in order to preserve the integrity of the judicial process and ensure successful domestic prosecution and inter-state cooperation. 


\section{Annex 1}

\section{List of Participating Experts}

Group 1: Improving international cooperation in the investigation \& prosecution of terrorist acts

- Anton Du Plessis (South Africa) - Co-chair

- Prof. Mike Newton (US) - Co-chair

- Prof. Elies Van Sliedregt, Klaas Rozemond and Vincent Glerum (The Netherlands)

- Joanne Mariner (Human Rights Watch)

- Judge Kimberly Prost (Canada)

- Martin Polaine (UK) and Arvinder Sambei (UK)

- Ranganath Manthripragada (US)

- Martin Ewi (OPCW)

- Tim Daniel (UK)

\section{Group 2: The use of force against terrorists}

- Prof. Andrea Bianchi (Italy) - Co-chair

- Michael Wood (UK) - Co-chair

- Prof. Steven Ratner (US)

- Prof. Elizabeth Wilmshurst (UK)

- Prof. Christian Tams (Germany)

- Prof. Claus Kress (Germany)

\section{Group 3: Intersection Between IHRL and IHL in the Fight against Terrorism}

- Helen Duffy (Interights, UK) - Co-chair

- Jelena Pejic (ICRC) - Co-chair

- Prof. Robert K. Goldman (US)

- Prof. David Kretzmer (Israel)

- Charles Garraway (UK)

- Prof. Claudia Martin (Argentina)

- Prof. Margaret Satterthwaite (US)

- Prof. Karima Bennoune (US)

\section{Observing experts participating on 30 and 31 March 2010}

- Prof. Tiyanjana Maluwa (Pennsylvania State University, US)

- Mr. Marten Zwanenburg (Ministry of Defence, The Netherlands)

- Ms. Liesbeth Lijnzaad (Ministry of Foreign Affairs, The Netherlands)

- Ms. Mireille Hector (Ministry of Foreign Affairs, The Netherlands)

- Mr. Fateh Azzam (OHCHR)

- Prof. Theo van Boven (Maastricht University, The Netherlands)

- Mr. Jean-Paul Laborde (Department of Political Affairs, UN)

- Ms. Joan Donoghue (State Department, US)

\section{Project Leaders}

- Dr. Larissa van den Herik (Grotius Centre, Leiden University)

- Prof. Nico Schrijver (Grotius Centre, Leiden University) 